\title{
Curating soya: Trying, testing and tasting (for) a sustainable museum
}

\author{
Magdalena Puchberger \& Nina Szogs
}

\begin{abstract}
The Volkskundemuseum Vienna has been subject to large conceptual changes and now focuses on its social role and contribution to an inclusive and democratic society. The soya project came to the museum coincidentally when a hidden historical conjuncture was revealed and offered an intriguing way to include the topic of climate change into the museum's agenda. The analogue and digital interactive formats in the soya project deal with the global contexts of climate change by analysing the social, economic and cultural role of the soya bean in our everyday lives. The authors present and discuss the inclusive museum approach, multisensory social programmes and the idea of a digital add-on exhibition on a small budget.
\end{abstract}

Keywords: Soya, climate change, curating climate, relational museum, democratic museum, permanent exhibition, social programme, online exhibition, cultural analysis, sensory ethnography

\section{CURATING SOYA IN AN ETHNOGRAPHIC MUSEUM}

The Volkskundemuseum Vienna is Austria's biggest ethnographic folk art and folk life museum and was founded in 1895. Since 1917, it has been located in the baroque Gartenpalais (Garden palace) Schönborn in the 8th district, near universities, theatres and other cultural institutions. In 1995, the permanent exhibition was renewed and reassembled and the museum aspired to get ready for the next millennium.

Twenty-five years and three museum directors later, the museum has changed and has had to change. Although, or maybe because of, being chronically underfunded, the museum is seeking to find its niche in the realm of the rich museum culture in Vienna and among the different museum approaches in the federal museums. Similarly, the museum is renegotiating its position in popular culture research and cultural analysis in Austria and within the diverse network of European ethnographic museums. In this process, one of the main principles has been established that defines the Volkskundemuseum Vienna as a public and open house.

Following this institutional restructuring process, the Volkskundemuseum Vienna ${ }^{1}$ took 
an institutional gap year in 2020 to reconsider the status quo further and conceptually define the ways the museum wants to work in the future. There were, consequently, no exhibitions planned for this period, but the work with the museum's collections was intensified, as was the conceptual planning of the future orientation of the museum regarding research, public engagement, co-operations, formats and much more. The museum aims to figure out how to contribute to a peaceful, equal and inclusive society that faces changing societal, ecological, epidemical, global and local conditions and times that are finite and critical. It seems to be existential, particularly for a small museum, to follow the guidelines of sustainability on financial, social and ecological levels. The careful and innovative employment of the museum's resources (such as collections, building, staff and networks) is crucial.

From 2018 onwards, we, the authors, started to follow these guidelines in our project Soya. Knowledge-Society-City, which is a small interdisciplinary and experimental project at the Volkskundemuseum Vienna. The soya project uses the exceptional significance that the Gartenpalais Schönborn holds for the history of soya production in Europe. Friedrich Haberlandt, a professor of agriculture, grew the very first soya plants of the Habsburg monarchy in the garden of the palais and laid - as a dominant narrative in Central Europe claims ${ }^{2}$ - the foundation of the global dissemination of soya.

This unique historical conjuncture initiated a multifaceted project on soya, focusing on the global and local contexts of farming, health and food security, the reasons for and the consequences of climate change, and on climate justice. The project offers online and offline visitors and readers diverse approaches to soya, informed by analyses and inputs from a great variety of actors in the field. The project further aims to connect knowledge and everyday practices from different people, such as scientists, activists and practitioners.

In this article, we will introduce you to our project, including the considerations and reflections of a museum of the future and its societal responsibilities and possibilities. Firstly, we will provide insights into the history and present situation of the Volkskundemuseum Vienna and how both are related to the field of soya. Secondly, we will elaborate and reflect on our soya concept and current formats in the project. In a third step, we will discuss our future plans on how to use and complement the given objects, structures, texts and narratives in the museum's permanent exhibition.

\section{THE ROLE OF ETHNOGRAPHIC MUSEUMS FOR THE DISSEMINATION, PRODUCTION AND EXCHANGE OF KNOWLEDGE IN THE FIELD OF CLIMATE CHANGE}

Ethnographic museums, particularly because of their troubled past, hold specific responsibilities for social justice in a global society. This concerns ethnological museums that have collected objects and stories under brutal or, at least, questionable circumstances in Europe's colonialist past. Accordingly, some museums now seek to offer communities a chance to convey their messages, for example, how they are affected by climate change and social injustice, and turn their museum "into a zone of real collaboration and supportive engagement across boundaries" (Newell 2017: 49).

Similar to these considerations, the Volkskundemuseum Vienna is in a constant process of redefining its role as an urban museum in Vienna, reflecting and dealing with its problematic role during the two dictatorships of Austrofascism and National Socialism in 
Austria (Puchberger \& Johler 2016: 183-225). How does a museum deal with its past and become an urban place for activism? In the museum's point of view, this is only possible when using inclusive and democratic museum approaches, such as those of a radically democratic museum and a relational museum.

According to museum theorist NoraSternfeld, a radically democratic museum requires five major tasks and processes: ${ }^{3}$ a) challenging archives (and collections), b) occupying space, c) organising a counter-public, d) producing (and offering) alternative knowledge, and e) radicalising cultural/museum education (Sternfeld 2018:37). She suggests understanding museums as a field of manifold negotiations and conflicts about existing conditions, such as the given infrastructure, the permanent exhibition and collections. A museum, furthermore, must integrate and reflect on societal, political or ideological discourses that are represented in the museum's publications or guided tours and workshops.

A relational museum, in the definition that we apply for our project, relates to specific (circum)stances, i.e. not being objective or equidistant but political and activist. The museum, thus, relates to themes and objects it presents and positions itself in the field. The challenge is to communicate these positions transparently and comprehensively, for example, by relating and connecting them to the living world and everyday life of visitors and guests. The authors in the introduction to the book Curating the Future summarise the concept of a relational museum very fittingly for the purposes of climate (inter)action:

A relational museum develops its authority through supporting and curating networks of related things and their significance, rather than delivering knowledge from a single vantage point. Museums are increasingly open to a flow in and out of the museum's structure, where audiences and collections, curators and designers are all in conversation in a mutually informing way, sharing authority. (Newell et al. 2017: 2)

The importance of these approaches lies not only in the case of climate change - in their empowering role for different groups of people. The social role and its significance for the democracy of museums is increasingly understood as one of the key tasks, because, as a quote from the joint conference introduction of the German Museum Association and the Network of European Museum Associations summarises: “[...] museums contribute through their daily business to society in dealing with questions that are connected to social cohesion, social inclusion and social diversity" (Conference: Museums and Social Responsibility: Values Revisited).

Consequently, the Volkskundemuseum Vienna's aim is to increase agency or, even before that, show that people have agency. At the same time, we walk a thin line between understanding that we can indeed make a change, while not releasing the major drivers of climate change from any liability. Hence, the task of the Volkskundemuseum Vienna when dealing with climate change is also to understand and analyse global mechanisms that cause climate change. For these purposes, soya has proved to be a useful tool and vehicle in the case of the Volkskundemuseum Vienna.

\section{VOLKSKUNDEMUSEUM VIENNA: FrAMING SOYA (HIS)STORIES}

The history of the Volkskundemuseum Vienna and the history of soya culminate in a very specific and long forgotten way. The building of the Volkskundemuseum Vienna is the 
frame of these two stories that are so tightly related - in the space and personal ties of the respective founding figures. This relationship was revealed to us coincidentally. In November 2017, the manager of research and development at the Central European non-governmental organisation DonauSoja approached the Volkskundemuseum Vienna with a surprising request. His organisation wished to install a commemorative plaque on the façade of the museum building to remember the "European soya pioneer Friedrich Haberlandt".

Although we had to reject this request, it had aroused our curiosity. This was due to the fact that the so-called soya pioneer, Friedrich Haberlandt (1826-1878), shared his family name with one of the founders and first director of the Volkskundemuseum Vienna, Michael Haberlandt (1860-1940), and his son and successor as director, Arthur Haberlandt (1889-1964).

Not only was the agronomist and expert on plant cultivation, Friedrich Haberlandt, the father of Michael and grandfather of Arthur Haberlandt, but it was also revealed that the first location of a soya plantation in Vienna (and in Austria) was indeed in the Gartenpalais Schönborn, the home of the Volkskundemuseum Vienna today. The Gartenpalais Schönborn was then the first domicile of the newly founded Viennese University of Agriculture.

\section{Soya plants: First contact at the world exhibition} in Vienna in 1873

Friedrich Haberlandt, the expert on plant cultivation and then first principal of the University of Agriculture, discovered soya beans and plants in the Chinese and Japanese sections at the world exhibition in Vienna in 1873 (Thiel 1872:1; N.N. 1873:1). He was fascinated by this plant and its potential regarding cultivation and people's nutrition from the beginning. Haberlandt was sure that soya would help the Habsburg monarchy to foster its agricultural standing in Europe and the world and bring essential advances in solving nutritional challenges of the monarchy (Puchberger 2019:24). His first basic and fundamental work on that subject Die Sojabohne (The Soya Bean; Haberlandt 1878) united the results of growing trials at Gartenpalais Schönborn and all over the monarchy with his predictions on the utilisations and patriotic benefits of this "miraculous alien" ("wunderthätiger Fremdling”, 1878:113).

Although Friedrich Haberlandt's success in growing and distributing soya in Austria, the monarchy and Europe was only mediocre, ${ }^{5}$ he can be considered a significant person in the further global history of soya. Due to his growing trials and belief in national and societal advancement through agricultural progress, Haberlandt played an important part in implementing and institutionalising agriculture as a leading and patriotic science in the Habsburg monarchy (Haberlandt 1874).

As another striking coincidence one generation later, his son Michael Haberlandt was one of the founders of yet another academic discipline that considered itself as essential for his homeland: the discipline of Volkskunde (folklore studies). A folklorist and Indologist, Michael Haberlandt was co-founder of the Verein Für Volkskunde (Folklore Society) in Vienna, the Österreichische Zeitschrift für Volkskunde (Austrian Journal of Folklore Studies) and of the Volkskundemuseum Vienna. The museum's initial name was the "Museum für österreichische Volkskunde" [Museum for Austrian Folk Art and Folk Life]. It was conceptualised with a strong patriotic 
and nationalist emphasis as a "monument" of the Habsburg monarchy and "remained so until long after the First World War" (Tschofen 1998:18).

In that period, the establishment of this kind of museum and the development of the academic discipline Volkskunde (Folklore Studies) were very common for intellectual, cultural and social movements all over Europe. Perhaps also inspired by the ethnographic exhibition of diverse (farming) houses at the world exhibition in Vienna, ${ }^{6}$ Michael Haberlandt started travelling throughout the whole monarchy (Haberlandt 1934:1f.) to collect, explore and compare pieces of tangible and intangible cultural heritage that he considered "typical" for the peoples of the monarchy. He was certain to find those "relics", particularly in the rural and remote areas of the monarchy, that were, as he and his colleagues feared, vanishing in the modern processes of urbanisation and industrialisation (Haberlandt 1896:183f). The objects and relics collected formed the basis of the Volkskundemuseum Vienna:

Over a third of the stocks were collected before 1918. An early emphasis was on furniture, textiles and ceramics, together with frequent serial collections of, for example, distaffs, flails for washing or products of different European cottage industries of the nineteenth Century. (Tschofen 1998: 18)

In the urban, metropolitan, centralistic Viennese contexts, the museum offered rurality, agriculture, peasants, and popular and folk cultures as a master narrative of "healing" forces for grievances of modern civilisation and urban societies. It took, invented and fostered a very special perspective on peasants, and their life and work and, thereby, idealised and ideologised rural life more than depicting it realistically (Johler \& Puchberger 2017).

Both Friedrich and Michael Haberlandt certainly supported the ideology of the monarchy and homeland and also the progress and development of the Austrian people with their work. Both were - although part of the urban academic elite - interested in rural and agricultural lifestyles and work routines. They can be understood as agents of the particular zeitgeist with idealistic goals.

Their approach to soya, agriculture or folk culture might help us to understand societal dynamics and discourses. The friction between the following dualities are of particular significance for our project: (1) the city and rural surroundings, (2) the centre and periphery, and (3) the bourgeois and peasant culture and everyday life. These forced dualities have been part of the museum, the building and their history from the beginnings. The analysis and the contexts of soya, the museum, and the academic and applied folklore help us to narrate and frame our (historical) approach and contrast or complement present manifestations. The different narratives concerning, promoting or rejecting soya, the idealistic goals and the conflicts or failures in the history of Austrian, European or global soya are inspiring sources to reflect present soya cultures.

\section{SOCIAL PROgRAMMES AND CURATING CLIMATE}

An important part of the ethnographic approach of the Volkskundemuseum Vienna is the disentanglement of complex phenomena to make them comprehensible for the local audience.

Consequently, for our museum, soya is an ideal starting point to talk about such complex 
topics as climate change, times of crises, nutrition and our daily diets, and a sustainable future. From our ethnographic perspective, we emphasise the cultural and social elements of climate change. Following the concept of Donna Haraway's "naturecultures" (Haraway 2003) in the field of soya, ethnographic and cultural anthropological approaches and methods help us to "mediate between dualisms, and identify the connectivity and synthetic properties of entities that are seemingly opposed" (Malone \& Ovenden 2017:1).

Kirsten Wehner argues accordingly for the case of museums that the dichotomy of Nature and Culture is indeed deep-seated in our institutions and, therefore, she advocates establishing new curatorial practices that reveal this historically constructed division (2017: 87). This deconstruction is of particular importance to fully fathom out the roots and causes of climate change and possible ways to mitigate its consequences. Hence, we need to understand climate change as a social and cultural phenomenon of capitalism and “progressivism” (Newell et al. 2017:6), before we can advocate for climate justice.

The Volkskundemuseum Vienna's goal is to take an active part in a diverse and informed narration of climate change. Or, as described on the Sustainable Development Goals Partnerships Platform of the United Nations:

Cultural institutions have unique physical sites, living and non-living collections, and scientific and humanities research capacities that can support locally-driven solutions, and nationally and globallysignificant changes [...]. (Sustainable Development Goals Partnerships Platform of the United Nations. Museum Partnerships for Future Earth)

Following these approaches and this understanding of the social role of museums, we can consider the unexpected connection of soya and the Volkskundemuseum Vienna via the building's history as "ethnographic serendipity" (Rivoal \& Salazar 2013). This is due to the fact that it is possible with the vehicle of soya or via the "soya-perspective" to connect the local and the global and the urban and the rural. Even more so, it enables us to deconstruct these binary concepts and to focus on the in-betweens. This is where soya production, distribution and consumption takes place and where climate change moves to the centre of our attention.

In accordance with this, the Austrian agricultural historian Ernst Langthaler discusses in his study on agri-food globalisation how soya is not only part of global food regimes but can be considered as the decisive factor that has had a profound impact on nature, culture and mankind. He even goes a step further to underline the relevance of soya for the world's recent past, present and future and suggests recognising the last phase of the Anthropocene as the "soyacene" (Langthaler 2019: 116).

When Langthaler thereby makes it utterly clear that global soya production is crucial to each and everyone's everyday life, we can only emphasise that this has also been one of the findings in our project on a small and local scale. The project's COVID-19 collection (\#SojaFromHome 2020) showed, for example, how soya can be part of foods and drinks, local food distribution, stock markets, cosmetics, pet food and animal fodder. Furthermore, scientific contributions on our online blog discuss how soya is highly disputed in the field of genetically engineered and modified foods, an existential factor in global animal food production and, thus, a major driver of climate change. However, at the same time, soya is ironically also a major factor of strategies to counter climate change with organic and vegan 
diets and celebrated for its potential to achieve global food security due to its high levels of protein (Elmadfa \& Meyer 2019; Vollmann 2019; Schlatzer 2020).

\section{SOYA FORMATS}

Utilising our different soya formats, our aim is to gather as much diverse information as possible in an open space for knowledge production and distribution. Thereby, we seek to enable an informed decision-making process, firstly, for the museum itself and, secondly, for (active) visitors and experts. We seek to answer and discuss questions, such as: Why and how is my Schnitzel or my salmon steak connected to the deforestation of the rainforest? How does the climate crisis relate to me and my nutritional needs in my local environment in Vienna? Why is soya not per se good or bad?

To answer these questions, we did not include the museum's permanent exhibition or collection at first. As elaborated above, the building and the specific history of the building were our starting points from which we explored other ties or coincidences relating soya to the museum, to historical and present phenomena and processes. Beyond exhibition rooms, we integrated other museum spaces such as the kitchen, the inner courtyard and the garden into the social programme. So far, we have, thus, followed museum approaches that understand museums as far more than the holder of collections and objects, as Karen Brown and François Mairesse summarise when discussing the social role of museums: "The last century has seen the purpose and values of the museum largely transformed to the point where, it could be argued, collections - once so central to museums - are considered of secondary importance today" (2018: 525).
The second year of the soya project was dedicated to practical and mediational work as a basis for further steps. Trying out new formats that had not yet included the permanent exhibition offered the opportunity to experiment with different kinds of knowledge, while staying flexible and adaptable simultaneously. We offered different kinds of formats for different audiences in terms of age, education and subculture and actively encouraged these different groups to mingle. We have also given speakers from different soya perspectives the floor: practitioners, producers, academics, food experts, activists and many more.

Regarding our social soya programmes, we have so far organised an academic symposium, an excursion to a manufacturing site for organic soya products and historical places of soya production in Hungary and Austria, as well as different kinds of soya fusion events, such as a speed dating event with local soya product producers and soya cooking classes.

Most of our programmes follow multisensory approaches that have shown themselves to also be helpful in ethnographic museums to offer the audience the possibility of learning about and contributing to a certain topic in multiple ways (Binter 2014). The possibility of learning more about a topic via a culinary experience has proven to be particularly helpful to address diverse audiences.

In our cooking classes, for example, a renowned tofu specialist and chef showed the audience how to include non-animal proteins, such as soya, in one's daily diet. Different people were invited to the open classes via the museum newsletter, social media channels and personally via informal networks. Many came to try, experiment and be culinarily surprised - and to ask questions. That was quite informative because the chef not only 
knows how to cook and entertain with (via) tofu but had a lot of background stories she had experienced since the 1980s. This made soya products and cooking itself more personal and, therefore, relatable.

At our fusion events, we combined the culinary experience with networking opportunities and marketplaces for local soya manufacturers, while contributing an input of the cultural analysis of soya. The fusion events also followed the idea of connecting fields and groups that are, on the one hand, integral to the soya theme or to the museum but, on the other hand, not related at first sight. On the first fusion event (called "Soja'n'Most") at the inner courtyard of the museum, we offered soya dishes and recipes in combination with Most (Austrian apple and pear wine) and discussed soya as an important Austrian crop. ${ }^{8}$ The second fusion event combined the historical connections to Asia, particularly to Japan, with the current manufacturing of soya products in Vienna. ${ }^{9}$

Similarly, the soya excursion was conceptualised as a multisensory experience of soya history in the Habsburg monarchy and the current global entanglements of soya production in Vienna and the surrounding agriculturalareas. With this event we particularly targeted members of the museum's association and students. Participants were able to observe and participate in the local process of soya production and visited historical venues in Hungary where the story of the Haberlandt family and that of the first soya growing trials in the Habsburg monarchy originated. Thereby, all participants were invited to discuss the role of soya in their everyday lives and actively contributed knowledge to the project.

One important basis for the whole project was the (academic) symposium at the very beginning of the project in 2018, where we were able to put an emphasis on the interand transdisciplinary nature of the topic. In co-operation with the Institute of Rural History (St. Pölten, Lower Austria), we were able to include perspectives from cultural anthropology, agricultural studies and other life sciences, while discussing the subject with representatives from NGOs, the chamber of agriculture and food trend experts. We were able to reflect the diverse roles that the soya bean plays in many areas of society and its impact on the climate. What was lacking, in a similar way to many other professional symposia, was the translation for a nonacademic and lay audience.

This is where we decided to set up an online blog called "MuSOJAm"10 that comprises many different voices from various fields of expertise. Thus far, it includes academic contributions, essays, reports, biographies, interviews and playful collections. ${ }^{11}$ Contributors originate from diverse fields, such as journalism, private households, academia, practice, civil society and schools and write or talk about topics such as food security, climate justice, botany and the history of soya. The blog is also the project's documentation platform, where people that have participated in our social programmes find a summary of the events and can - as everybody - dive deeper into the field of soya. The blog and the hashtag \#SojaFromHome were decisive steps into another arena: Our newest blog posts as well as observations on soya-related topics and issues were the basis for the presence of the project on the museum's social media channels. We tested Twitter, Facebook and Instagram for their potential as a low-threshold approach and opportunity to communicate. All this collected multifaceted knowledge will now serve as the basis for the development of our so-called soya add-on exhibition as part of the permanent 
exhibition of the Volkskundemuseum Vienna. The project blog is thus one of our key sources for the development of the add-on exhibition. It allows us to stay in contact and exchange with interested groups and disseminate the knowledge gathered and related educational programmes independently from the museum location.

Our colleague Katrin Prankl has developed a cultural educational programme for children and school groups that entails a scavenger hunt in the permanent exhibition and includes experimenting with the growing trials of soya plants in the museum garden. While doing so, our guide tells the children playfully about global transport, production, agriculture, animal welfare and the nutritional contents of the soya bean (Prankl 2019). Although there have already been some guided tours for school classes in the museum, we were forced to adapt our programme several times in the process. At first, our museum was put into a financially very challenging situation (2019), then the museum was closed because of the COVID-19 lockdown and restrictions.

\section{EXHIBITING SOYA}

Even though we have used the permanent exhibition only randomly for our project up to now, we see a strong connection between the analysis of soya and topics and objects exhibited in the Volkskundemuseum Vienna. The plan is to use the permanent exhibition from 1995 as an anchor and reference point that reveals the links that soya has to the history of the museum, the discipline and its narratives.

The permanent exhibition dates back to 1995 and was conceptualised and curated by the then director Klaus Beitl and curator Bernhard Tschofen. Tschofen wrote in his first programmatic chapter of the catalogue accompanying the new permanent exhibition about changing the approaches to artefacts in the collections of the Volkskundemuseum Vienna based on folk art:

The significance of artefacts is constantly changing. The museum of cultural studies, as a place where they are interpreted, contributes to this and determines how things appear, what they represent and what information they convey. Therefore museum presentations cannot remain constant but from time to time must subject idea, content and appearance to fundamental revision. During such reorganization phases questions naturally emerge which both relate to the basic possibilities of museum work and are directed at the specific problems of how to treat the relics of popular culture. The answers are bound to be subjective, but must nevertheless be well-founded. (Tschofen 1998: 15f)

The idea of "democratizing museums" which was discussed in 1995 - was pursued by emphasising "the history of everyday life instead of popular art, and function instead of beauty", which meant to leave former aestheticised design and exhibition principles at the Volkskundemuseum Vienna behind. To "contradict" the museum's collections, the artefacts exhibited were presented as "witnesses to the past as a result of changes in the way of life and in values" (Tschofen 1998:16) instead of former disciplinary beliefs of folk art artefacts being manifestations of a hardly changing, stable folk culture. The permanent exhibition tells the master narrative of the academic and applied discipline and the collections of Volkskunde in Austria and discusses national, regional and social strategies of identifying and othering.

We still see and appreciate the structure and the goals of this exhibition - but times and 
approaches are changing. Today, "democratizing museums" means something different. It means, as discussed above, to activate and generally invite more people, groups and approaches to take part in the museum's processes and utilisations. Consequently, over the last few years, it has become increasingly visible that the exhibition and its narrative are fragmentary. Nowadays, we identify an increasing number of gaps - people, subjects and objects that are missing. There are actors that are not mentioned, contexts that are invisible, opportunities to present dynamics and societal challenges that are lacking.

\section{INTERVENTIONS AND ADD-ONS}

There have already been various interventions in the permanent exhibition over recent years. In 2017, for example, as a result of a four-year research project (Strategies for Museums in Times of Political Upheaval, 2010-2014), the museum reflected on its own problematic (however societally and culturally very effective) nationalistic history in the periods of the two totalitarian regimes of Austrofascism and National Socialism. Part of the project was also to critically discuss the narrative of the permanent exhibition (Johler \& Puchberger 2017). The aim of this exhibition or intervention was to spotlight the actors of the folk culture scene in Vienna at that time whose diversity has not yet been made visible in the permanent exhibition. In addition to academic and bourgeois actors, for example, there were also lower middle-class or workingclass actors who were important for creating and disseminating the idea and ideologies of a folk culture.

In 2018, a permanent intervention was installed into the permanent exhibition that put a finger on a particular weak spot. The exhibition intervention "The Shores of Austria" (Daher et al. 2018) was created by a collective of curators ${ }^{12}$ who have had their own experiences with migration or asylum procedures in previous years. The collective intervened in the permanent exhibition with the curators' quotes of their experiences and with objects that stem from a collection journey to the Greek islands and other refugee- and asylumrelated contexts. The current director of the Volkskundemuseum Vienna, Matthias Beitl, summarised the achievements of the curating collective that had managed "to create a necessary historic controversy between objects in a museum and the blind spots of the societal doctrine and its institutions. That is something new - and something never-ending" (Beitl 2018: 13).

\section{Adding on SOYA - A Digital trial}

Working on the soya project and dealing with soya contexts and discourses for more than two years (at the time of writing) showed that there are blind spots in the permanent exhibition in terms of climate change. ${ }^{13}$ These blind spots can be compensated by including the perspectives in a soya add-on exhibition: (1) reflecting the historical impact of academic and applied folklore studies in the field; (2) integrating (agri)cultural labour and knowledge by giving practitioners a voice and their own perspective; (3) observing different lifestyles; (4) thinking and discussing genderand class-specific aspects; (5) calling attention to the global conditions and their local consequences; and (6) pointing to social and global hierarchies and injustices.

Due to the fact that there has already been one analogue intervention added to the permanent exhibition, we refrained from putting yet another layer of information onto 
the analogue narrative. Instead, we decided to experiment with an online exhibition which will work as an add-on, while walking through the exhibition in real life and also independently as an online exhibition. The COVID-19 lockdown, the importance of the digitalisation of museums and the fact that the soya project already takes place online to a great extent supported this idea. ${ }^{14}$

The permanent exhibition, its structure, narratives and objects, indeed offer many links to the soya field. The different exhibition rooms and themes as well as separate objects offer various possibilities to connect the idea of the permanent exhibition with our soya intentions.

Taking a look at the description (fig. 1 \& 2) of the permanent exhibition, we find that nutrition, cooking, transport, farming, trade, milieus and specific lifestyles are among the main topics. All these are crucially related to global warming, the climate crisis and global injustice. However, global warming, even though it already existed in the 1990s, is today one of the biggest gaps in the permanent exhibition. The connection of the museum's building to the history of soya in Austria was, therefore, a decisive and urgent impact to include this critical field to the museum's narrative.

We will - with all the knowledge gathered from the different actors in the project develop our own story by following the permanent exhibition's track and storyline and we plan to transform the existing narrative by linking themes and objects to soya. Some examples might clarify the idea of the online exhibition that will also be the basis for the future educational programme:

a) The exhibition room "Nature and Civilisation" deals with pre-industrial and agricultural materials and tools. In our soya add-on, we will talk about the soya plant itself, soya cultivating and soya breeding as genetic engineering.

b) The exhibition rooms "Fire, Hearth and Oven" and "Cultural Patterns and Characteristics of an Era: Upper Inn Valley Farmhouse Parlour" connect two important aspects: The exhibition room "Fire, Hearth and Oven" leads to nutrition, cooking and historical expertise and to the topic of food security. This room is related to the next room which is a historical Tyrolean parlour. The intervention "Shores of Austria" mentioned previously has installed a video in the windows of the parlour showing a rescue boat in the Mediterranean Sea. This installation is our link to migration provoked by the climate crisis.

c) The exhibition rooms "Pre-Modern Transport" and "Paths, Goods, Markets" are the basis of our considerations regarding the global and Austrian transport systems and the logistic infrastructure of soya, the main producers and distributors and the impact of this global interconnectedness.

The work with the permanent exhibition within the soya project will continue but can only fill some of the gaps. Nevertheless, the permanent exhibition is also a document of societal change that we can use to highlight changing narratives, social transformation and institutional developments.

\section{CONCLUSION AND OUTLOOK}

The soya project has been a very special project at the Volkskundemuseum Vienna. From the very beginning, it was a small project 


\section{Magdalena Puchberger \& Nina Szogs}

Preface

Popular Culture in the Museum

Folk Culture - Discovery and Invention

The Ethnographic Perspective

Man and Environment

Nature and Civilization

The Cultivated Landscape

Fire, Hearth and Oven

Cultural Patterns and Characteristics of an Era:

Upper Inn Valley Farmhouse Parlour

Home Decorative Style:

Chests, Cupboards and Chairs from Tyrol and

Vorarlberg

Regional Stylistic Variation: The Montafon Parlour.

Man and Economy

Agriculture

Pre-modern Transport

Parhs, Goods, Markets

Doestic Economics

Myth

The Order of Existence

Man and History

The History of the People

Peoples and Imagery

History and Religion: Catholic and Protestant Rural

Furniture

Man and Society

Estate Culture

Pastoral Pride: Upper Austrian Rural Furniture

Lifestyles in Transition

Select Bibliography

Fig. 1. Description of the permanent exhibition

(Austrian Museum of Folk Life and Folk Art.

Österreichisches Museum für Volkskunde 1998: 5).



Fig. 2. Back cover of the booklet of the permanent exhibition (Austrian Museum of Folk Life and Folk Art. Österreichisches Museum für Volkskunde 1998). 
that got the chance to function as a field of experimentation for further orientation and future museum formats. Our resources and coverage were small, but the project integrated so many different and inspiring aspects that the energy and the enthusiasm were high. The project enabled new and fruitful approaches, co-operations, formats and - last but not least - contacts with clever, dedicated and constructive people in Vienna, Austria and in global contexts.

Since a huge budget was not involved and do not get us wrong, this would have been our preferred way to go - it allowed us, nevertheless, to be honest with ourselves where our formats did not work out the way we intended. One example was the inclusion of women's voices from academia to an equal amount of men's voices, which we did not achieve, partly because of the lack of women in the research field in, for example, agricultural sciences. Similarly, in our cooking classes, we tried to reach a diverse group of people. Whereas we were successful in terms of age, exclusively women with a very similar social background participated in the classes.

Around the same time as the soya project started, Greta Thunberg initiated the global Fridays For Future movement. What we would not have expected was the impact that the soya project and the movement have had directly and indirectly on the museum's sustainability agenda and on our private lives. In 2019, a museum group for sustainability was founded and has tried to figure out ways to improve sustainability at the Volkskundemuseum Vienna. Luckily, we have an expert on the big issue of preventive conservation. In addition to that, the museum started changing and adapting the recycling system, food delivering services, cleaning products and much more. Finally, the museum participated in the global climate strike in September 2019, which also initiated and mobilised not only Viennese museums to participate. At the workshop "Curating Climate"15 we connected with international scholars and activists who work for museums, on exhibitions and deal with the climate crisis. In Austria, we are part of the Austrian (Viennese) Museums For Future group and in regular contact with activists and colleagues in other institutions. We support local Fridays For Future groups by offering them space and infrastructure to meet and organise, as suggested in the Museums For Future declaration (Museums for Future 2020).

We recognised the power of the movement and the importance of analysing and informing about climate change, climate justice and sustainability via the soya project in our own lives. It was quite eye-opening and inspiring, particularly in the field of food and diets. In the process of the project, we learned how much (practical) knowledge and peer support is necessary to change something so defining to people as their diets and routines. It worked best when people made us curious to try something new. The food expert and chef Elisabeth Fischer (Fischer 2013) was one of the key people in this process. Her cooking classes worked without dogma but instead focused on the culinary pleasure of soya products and other plant-based products, while not excluding animal products in general for those who wanted to include them. Informing, learning by doing and showing passion turned out to be effective and expedient.

\section{Notes}

1. The museum has changed its name in German and in English over the years. The name used to be the Österreichisches Museum für Volkskunde 
and has now changed to Volkskundemuseum Wien; the English translation changed from the Austrian Museum of Folk Life and Folk Art to Volkskundemuseum Vienna.

2. This narrative is of particular interest because, on the one hand, Haberlandt was one of the first scientists to experiment with the soya plant in Central Europe. On the other hand, the narrative is also driven by soya production lobbying groups and additionally must be interpreted in the context of the Habsburg empire (MuSOJAm. Soja im Museum 2019).

3. Original: "a) Das Archiv herausfordern, b) Den Raum aneignen, c) Gegenöffentlichkeit organisieren, d) Alternatives Wissen produzieren, e) Vermittlung radikalisieren" (Sternfeld 2018:37).

4. The reply was negative because the Volkskundemuseum Vienna has a clear memory policy since it decided to have only one commemorative plaque on the facade. This plaque is dedicated to Jewish benefactors and collectors that contributed to the museum from the institution's beginnings until 1938. Some of them were murdered in the National Socialist extermination camps. The commemorative plaque for Friedrich Haberlandt is now installed near to the museum at the home of the Haberlandt family at Löwenburggasse.

5. One of the reasons Haberlandt could not continue his work was because he died in an accident in 1878.

6. Michael Haberlandt's brother Gottfried Haberlandt mentions the family trips to the world exhibition in his memoirs (Haberlandt 1933:53).

7. At this event we co-operated with the "Mostothek", that serves must and fruit juices every Tuesday at the Volkskundemuseum Vienna and the Austrian Soya NGO Soja aus Österreich (Soya from Austria).

8. Soya is fourth after corn, wheat and barley (Soja aus Österreich) in the official Austrian agricultural area statistics.
9. We co-operated with the curator of the East Asia collection at the Weltmuseum (ethnographic museum for non-European cultures; https:// www.weltmuseumwien.at/en/curatorialdepartments/\#ostasien) in Vienna, where the boxes with the first soya beans in Austria are exhibited, and again with the Soya NGO Soja aus Österreich.

10. You will find the blog (in German) following this link: https://musojam.blog/.

11. We started a collection called \#SojaFromHome in line with the successful Corona-Hashtag \#MuseumFromHome during the Corona lockdown which has occurred in many European countries.

12. The curators of the exhibition "The Shores of Austria. The New Collection on View of the Austrian Museum of Folk Life and Folk" are Yarden Daher, Alexander Martos, Negin Rezaie, Ramin Siawash, Niko Wahl, Sama Yasseen and Reza Zobeidi.

13. For us, the year 2019 offered opportunities to discover and reflect new ways of narrating and curating climate (change). At the workshop "Curating Climate - Museums as 'contact zones' of climate research, education and activism" in Oslo, October 2019, we learned about diverse approaches to the field, such as "climate houses" (Bremerhaven and Oslo) or new museum projects that integrate sustainable principles in social and educational programmes to existing exhibitions. Also, in Vienna narrations of climate change are prominent parts of current museum and exhibition projects. This includes the art museums MAK (https://mak. at/en/creativeclimatecare) and Kunst Haus Wien (https://www.kunsthauswien.com/en/ exhibitions/nach-uns-die-sintflut/) or the technical museum "Technisches Museum Wien" (https://www.technischesmuseum.at/press/ corona-impact).

14. The NEMO "Working Group on Digitalisation 
and Intellectual Property Rights" has published a report on "Digitisation and IPR in European Museums" underlining the importance of further progress in digitalising European museums (NEMO Working Group on Digitalisation and Intellectual Property Rights 2020).

15. Workshop: "Curating Climate - Museums as 'contact zones' of climate research, education and activism" in Oslo, October 2019. Many thanks to the organisers who initiated and enabled such an important exchange.

\section{REFERENCES}

\section{Internet Sources}

Elmadfa, Ibrahim \& Alexa L. Meyer 2019. "Die Bedeutung der Sojabohne für die Ernährung des Menschen" [The meaning of the soya bean for people's nutrition] Retrieved from: https:// musojam.blog/2019/08/26/die-bedeutung-dersojabohne-fur-die-ernahrung-des-menschen/ (Published 26 August 2019).

Museale Strategien in Zeiten politischer Umbrüche 2020. Das Österreichische Museum für Volkskunde in den Jahren 1930-1950 [Strategies for Museums in Times of Political Upheaval: The Austrian Museum of Folk Life and Folk Art in the Years 1930-1950]. https://www.volkskundemuseum. at/museale_strategien_in_zeiten_politischer_ umbrueche (Accessed 24 September 2020).

Museums For Future 2020. https://museumsforfuture. org/ (Accessed 24 September 2020).

MuSOJAm 2019. "A discussion among Matthias Beitl (Director of Volkskundemuseum Vienna), Magdalena Puchberger and Nina Szogs." In Soja im Museum [Soya in the Museum]. Retrieved from: https://musojam.blog/2019/06/18/ musojam-soja-im-museum/ (Accessed 19 June 2019).

NEMO Working Group on Digitalisation and Intellectual Property Rights 2020. "Digitisation and IPR in European Museums." In Network for European Museum Organisations. Retrieved

from: https://www.ne-mo.org/fileadmin/Dateien/ public/Publications/NEMO_Final_Report_ Digitisation_and_IPR_in_European_Museums_ WG_07.2020.pdf (Published July 2020).

Prankl, Katrin 2019. Vermittlungsarbeit im Museum: "Soja - so lala". In In Soja im Museum [Soya in the Museum]. Retrieved from: https://musojam. blog/2019/11/04/vermittlungsarbeit/ (Published 4 November 2019).

Schlatzer, Martin 2020. "Regenwaldbrände, Soja und Fleischhunger" [Burning rain forests, soya, and hunger for meat]. In Soja im Museum [Soya in the Museum]. Retrieved from: https://musojam. blog/2020/01/08/regenwaldbrande-soja-undfleischhunger/ (Published 8 January 2020).

Soja aus Österreich. Zahlen Daten. https://sojaaus-oesterreich.at/zahlen-daten/ (Accessed 22 September 2020).

Sustainable Development Goals Partnerships Platform of the United Nations. Museum Partnerships for future earth. Retrieved from: https://sustainabledevelopment.un.org/ partnership/? $\mathrm{p}=22581$ (Accessed 15 August 2020).

Vollmann, Johann 2019. “Sojabohne: Von genetischen Ressourcen zu modernen Lebensmitteln und so weiter" [Soya bean: From genetic resources to modern food and so on]. In Soja im Museum [Soya in the Museum]. Retrieved from: https:// musojam.blog/2019/06/18/sojabohne-vongenetischen-ressourcen-vollmann/ (Published 18 June 2019).

\#SojaFromHome 2020. "Eine Covid-19-Sammlung" [\#SoyaFromHome. A Covid-19 Collection]. In Soja im Museum [Soya in the Museum]. Retrieved from: https://musojam.blog/sojafromhome/ (Accessed 1 September 2020).

Weltmuseum. East Asia: China, Korea, Japan. https://www.weltmuseumwien.at/en/curatorialdepartments/\#ostasien (Accessed 22 September 2020). 


\section{LITERATURE}

Austrian Museum of Folk Life and Folk Art.

Österreichisches Museum für Volkskunde 1998

[in German 1994]. Display Collection of Historical

Popular Culture. Booklet accompanying the

permanent exhibition of the Austrian Museum of

Folk Life and Folk Art. Vienna: Österreichisches

Museum für Volkskunde, Verein für

Volkskunde.

Beitl, Matthias 2018. "Broken Promises." In Yarden

Daher, Alexander Martos, Negin Rezaie, Ramin

Siawash, Niko Wahl, Sama Yasseen \& Reza

Zobeidi (eds.). The Shores of Austria. The New

Collection on View of the Austrian Museum of

Folk Life and Folk Art. Vienna: Österreichisches

Museum für Volkskunde, 12-13.

Binter, Julia T.S. 2014. "Unruly Voices in the Museum."

The Senses and Society 9:3, 342-360.

Brown, Karen \& François Mairesse 2018. "The

definition of the museum through its social role."

Curator 61, 525-539.

Daher, Yarden \& Alexander Martos, Negin Rezaie,

Ramin Siawash, Niko Wahl, Sama Yasseen, Reza

Zobeidi (eds.) 2018. The Shores of Austria. The

New Collection on View of the Austrian Museum

of Folk Life and Folk Art. Vienna: Österreichisches

Museum für Volkskunde.

Fischer, Elisabeth 2013. Soja: 120 vegane und vegetarische Rezepte mit Tofu, Sojacreme \& Co.

Wien: Kneipp Verlag.

Haberlandt, Friedrich, 1874. "II. Landwirthschaftliche

Nutzpflanzen und ihre Producte." In Jos. R.

Lorenz (ed.). Die Bodencultur auf der Wiener

Weltausstellung. Die Landwirtschaft und ihre

Hilfsgewerbe auf der Wiener Weltausstellung 1973.

Vienna: Faesy \& Frick, 50-94.

Haberlandt, Friedrich 1878. Die Sojabohne.

Ergebnisse der Studien und Versuche über die

Anbauwürdigkeit dieser neu einzuführenden

Culturpflanze. Vienna: Carl Gerold's Sohn.

Haberlandt, Gottfried 1933. Erinnerungen.
Bekenntnisse und Betrachtungen. Berlin: Julius Springer.

Haberlandt, Michael 1896. "Die Photographie im Dienste der Volkskunde." Zeitschrift für Österreichische Volkskunde II, 183-186.

Haberlandt, Michael 1934. "Geschichte eines Lebenswerkes. Vierzig Jahre Museum für Volkskunde." Neues Wiener Tagblatt, 12 October, 1-2.

Haraway, Donna 2003. The Companion Species Manifesto: Dogs, People, and Significant Otherness. Chicago: Prickly Paradigm Press.

Johler, Birgit \& Magdalena Puchberger 2017. Making:heimat. The Museum of Folk Life and Folk Art in Vienna between the Everyday and the Political. Accompanying Booklet to the exhibition 18 October 2017 till 11 March 2018 at the Volkskundemuseum Vienna. Vienna: Österreichisches Museum für Volkskunde.

Langthaler, Ernst 2019. "Ausweitung und Vertiefung. Sojaexpansionen als regionale Schauplätze der Globalisierung." Österreichische Zeitschrift für Geschichte / Austrian Journal of Historian Studies 30, 115-146.

Malone, Nicholas \& Kathryn Ovenden 2017. „Natureculture“. In The International Encyclopedia of Primatology. Hoboken/New Jersey: John Wiley \& Sons. https://onlinelibrary.wiley.com/ doi/pdf/10.1002/9781119179313.wbprim0135 (Accessed 22 September 2020)

N.N. 1873. "Die Weltausstellung des Jahres 1873 in Wien." Wiener Landwirthschaftliche Zeitung, 3 May, 1.

Newell, Jennifer 2017. “Talking around objects. Stories for living with climate change." In Jennifer Newell, Libby Robin \& Kirsten Wehner (eds.). Curating the Future: Museums, Communities and Climate Change. London, New York, N.Y.: Routledge, 34-49.

Newell, Jennifer, Libby Robin \& Kirsten Wehner 2017. "Introduction: Curating connections in a climatechanged world." In Jennifer Newell, Libby Robin \& Kirsten Wehner (eds.). Curating the Future: 


\section{Curating Soya: Trying, TESTING AND TASTing (FOR) A SUSTAINABLE MUSEUM}

Museums, Communities and Climate Change.

London, New York, N.Y.: Routledge, 1-16.

Puchberger, Magdalena 2019. "Eine Bohne für alle

Krisen.” Die Furche, 15 July, 24.

Puchberger, Magdalena \& Birgit Johler 2016.

"Wer nutzt Volkskunde? Perspektiven auf

Volkskunde, Museum und Stadt am Beispiel des

Österreichischen Museums für Volkskunde in

Wien." In Österreichische Zeitschrift Volkskunde,

183-225.

Rivoal, Isabelle \& Noel B. Salazar 2013.

"Contemporary ethnographic practice and the

value of serendipity." Social Anthropology 21,

178-185.

Sternfeld, Nora 2018. Das radikaldemokratische Museum. Vienna: De Gruyter.

Thiel, Hugo 1872. "Die Landwirthschaft und die Weltausstellung in Wien 1873." Wiener Landwirthschaftliche Zeitung, 1 June, 1.

Tschofen, Bernhard 1998. "Popular Culture in the Museum or: one must imagine everyday life." In Austrian Museum of Folk Life and Folk Art. Österreichisches Museum für Volkskunde Art. Display Collection of Historical Popular Culture. Booklet accompanying the permanent exhibition of the Austrian Museum of Folk Life and Folk Art. Vienna: Österreichisches Museum für Volkskunde, Verein für Volkskunde, 15-26.

Wehner, Kirsten 2017. “Towards an Ecological Museology. Responding to the Animal-objects of the Australian Institute of Anatomy Collection."
In Jennifer Newell, Libby Robin \& Kirsten

Wehner (eds.). Curating the Future: Museums, Communities and Climate Change. London, New York, N.Y.: Routledge, 85-100.

\section{Conferences:}

German Museums Association and Network of European Museum Organisations: Museums and Social Responsibility: Values Revisited. 17-18 September 2020. Retrieved from: https://www. museumsbund.de/wp-content/uploads/2020/09/ programm-eu-konferenz.pdf (Accessed 15 September 2020).

Curating Climate - Museums as 'contact zones' of climate research, education and activism. Workshop at Oslo School of Environmental Humanities. Retrieved from: https://www.hf.uio. no/english/research/strategic-research-areas/ oseh/news-and-events/events/workshops2/ curating-climate.html (Accessed 25 September 2020).

Magdalena Puchberger, ethnographer and historian.

Volkskundemuseum Wien

Laudongasse 15-19, 1080 Wien, Austria magdalena.puchberger@volkskundemuseum.at

Dr. Nina Szogs, researcher and ethnographer. nina.szogs@posteo.org 